\title{
THE IDEOLOGICAL FOUNDATIONS OF THE PROFESSIONAL TRAINING OF MODERN DOCTORS: PHILISOPHICAL AND BIOETHICAL ASPECTS
}

\author{
О. М. Христенко
}

\section{Тернопільський національний медичний університет імені І. Я. Горбачевського МОЗ України ІДЕЙНІ ЗАСАДИ ПРОФЕСІЙНОЇ ПІДГОТОВКИ СУЧАСНИХ ЛІКАРІВ: ФІЛОСОФСЬКО-БІОЕТИЧНИЙ АСПЕКТ}

\begin{abstract}
The task of modern higher medical education in Ukraine is to provide professional training for future doctors on the relevant principles of philosophy and bioethics involving knowledge, values, attitudes and behavior within the category "moral responsibility of a doctor".

This paper is dedicated to basic modern philosophical and bioethical concepts which are related to the moral responsibility of the doctor for human life, as well as analysis of their axiological essence.

Research methods: content analysis and comparative analysis.

Feminist bioethics seeks to show the special, exceptional value of a woman's spiritual world; at the same time the dependence of her social position on the traditional patriarchal society is taken into account. Therefore, when it comes to abortion, women's interests are dominant.

In contrast, conservatives and Christians protect the unborn child's right to life. But now secularism, more assertive in Europe than elsewhere, proposes the exclusion of religious belief and expression from public life. In aspiring to be the legitimate judge of the religious sphere, secularism claims not merely separation from religion but control over it.

Besides, there is serious discussion on the morality of abortion under conditions of some medical indications, assumptions or forecasts. For instance, concerning a fetus with Down syndrome. On the one hand, this is a serious genetic disease that can cause a difficult life for the child and his or her parents. On the other hand, these special children can even be very talented and achieve great success in various fields of social life, especially in the arts and sports.

So, it is defined that ideological foundations of modern doctor must be based on the humanistic values' system. It means that health, safety and life of human, including unborn child, have to be accepted as the highest values. Moral responsibility of doctor is related to implementing of these values into practice.
\end{abstract}

Key words: doctor; philosophy; bioethics; abortion; feminism.

Анотація. Завдання сучасної вищої медичної освіти в Україні - забезпечити професійну підготовку майбутніх лікарів згідно з відповідними принципами філософії та біоетики, що передбачають знання, цінності, ставлення та поведінку в межах категорії «моральна відповідальність лікаря». Ця стаття присвячена основним сучасним філософським та біоетичним концепціям, пов’язаним із моральною відповідальністю лікаря за життя людини, а також аналізу їх аксіологічної сутності.

Методи дослідження: контент-аналіз та порівняльний аналіз.

Феміністська біоетика прагне показати особливу, виняткову цінність духовного світу жінки; водночас враховується залежність ії соціального становища від традиційного патріархального суспільства. Відтак, коли йдеться про аборт, інтереси жінки є домінуючими.

На противагу, консерватори та християни захищають право ненародженої дитини на життя.

Але нині секуляризм, більш радикальний у Європі, ніж деінде, пропонує виключити релігійну віру та їі вираження із суспільного життя. Прагнучи бути законним суддею релігійної сфери, секуляризм вимагає не просто відокремлення від релігії, а контролю над нею.

Крім того, існує серйозна дискусія щодо моральності абортів за умов певних медичних показань, припущень чи прогнозів. Наприклад, щодо плода з синдромом Дауна. 3 одного боку, це серйозне генетичне захворювання, яке може спричинити важке життя дитини та її батьків. 3 іншого боку, ці особливі діти навіть можуть бути дуже талановитими та досягати великих успіхів у різних сферах суспільного життя, особливо у мистецтві та спорті.

Отже, визначено, що ідейні основи сучасного лікаря повинні базуватися на системі гуманістичних цінностей. Це означає, що здоров’я, безпека та життя людини, у тому числі ненароджених дітей, повинні бути прийняті як найвищі цінності. Моральна відповідальність лікаря є пов'язаною з упровадженням цих цінностей у практику.

Ключові слова: лікар; філософія; біоетика; аборт; фемінізм.

(C) O. M. Khrystenko 


\section{Materials of International Scientific and Practical Conference \\ "PROFESSIONAL AND COMMUNICATION CULTURE OF THE FUTURE DOCTOR: LINGUISTIC, PEDAGOGICAL AND PHILOSOPHICAL ASPECTS”}

Introduction. We live around the turn of the millennium that is characterized by scientific and technological achievements in the fields of genetics, embryology, reproductology, resuscitation and clinical medicine in general. But at the same time there are a number of unresolved problems, contradictions on the morality of abortion, embryo experiments, fetal therapy etc.

Worldwide discussion on the identification of the status of an unborn child, moral responsibility of the doctor for abortion, euthanasia, the impact of religion on medicine and the like questions requires the professional ability of future Ukrainian doctors to make appropriate decisions. Therefore, students of the medical university must have a humanitarian outlook.

The basis of this worldview are philosophical ideas that provide an understanding of current health issues, first of all, bioethical, according to defined value system. Therefore, the task of modern higher medical education in Ukraine is to provide professional training for future doctors on the relevant principles of philosophy and bioethics involving knowledge, values, attitudes, behaviors within the category "moral responsibility of a doctor".

Since the sources of any methodology are scientific concepts, theories, approaches, it is important to consider them in the professional training of specialists. in our case, students of medical institutions of higher education should know the peculiarities of the latest scientific ideas of philosophical and bioethical discourse. It will help future doctors to be able to solve professional problems by objectively analyzing them from different perspectives.

The aim - to represent basic modern philosophical and bioethical concepts, theories, approaches related to the moral responsibility of the doctor for human life, as well as to analyze their axiological essence.

Methods. In order to identify peculiarities of the philosophical and bioethical concepts, theories and approaches. We use content analysis and comparative analysis; to define their value systems we use axiological approach.

Results. Today there are a number of theories that seek to influence decision making in the medical field by promoting their own value system. Then we will analyze in detail the main ones. So, we have Feminist Bioethics which is an area of applied philosophy that explores ethical issues arising from healthcare, medical technology, or health policy from a feminist perspective. Actually, it is a subfield of both bioethics and feminist ethics, and extends into sociology, law and history, and philosophy of science and medicine. Feminist bioethics was originally identified with works relating to the ethics of abortion and ethical issues surrounding reproduction technology. The scope of feminist bioethics has extended into bioethics and health policy more generally because of its feminist concern to challenge oppression, subordination, and disadvantage as they relate to healthcare, health policy, and biotechnology [2]. Feminist bioethics seeks to show the special, exceptional value of a woman's spiritual world; at the same time the dependence of her social position on the traditional patriarchal society is taken into account.

"Freedom, rights and interests of women in health care" - that is how the feminist bioethics slogan might sound. In general, human freedom should be related to good. In this context, women's freedom means in particular freedom of choice. Is it good? Yes, it is. No doubt! Representatives of feminist bioethics interpret women's freedom as an absolute value and claim that a woman has the right to choose - either to have an abortion or to allow an unborn baby to live and be born. Feminists have even come up with a slogan about it: "My body is my business".

Obviously, this position causes a number of contradictions: firstly, one person's freedom must not harm another, secondly, according to scientific research, unborn child is not just part of the mother's body but a separate human being with a distinct personality and self-development program, thirdly, an unborn child has a unique value as a spiritual being ("foetuses have the same moral status as ordinary adults" [5]). According to the anti-abortion substance view theorist, induced abortions - whether by killing or letting die - are immoral because they fail to recognize that the human fetuses, from conception or soon afterwards, are full moral agents with inherent moral worth, the loss of which is one of the greatest possible losses. On this view, induced human abortion is not a minor moral failing, but a deeply immoral action [6].

Besides, it is important to consider about feminists' view on selective abortion. Although a preference for sons is a universal phenomenon, in some developing countries daughters are considered financial and cultural liabilities. Invention of ultrasonography resulted in widespread gender screening and selective abortion of normal female foetuses in many countries, for example, in the Far East. Actually, feminists take different, even divergent positions on the morality of such kind of 
abortion. And it is not unexpectedly. On the one hand, feminists oppose discrimination against women in general (it might be extend to unborn girls too), on the other hand, abortion as the women's right must be first priority for them. So, there is distinct contradiction between unborn girls' right to life and women's right to abort pregnancy. The main question arises under these circumstances: what must be more valuable the freedom of a woman or the life of an unborn girl?

Feminists from India have strongly opposed it, considering it as a further disenfranchisement of females in their patriarchal society, and have agitated successfully for legislative prohibitions. Libertarian feminists on the other hand, primarily from the United States, have argued that any prohibition of the use of this technology is a curtailment of a woman's reproductive choices and a violation of her right to make autonomous decisions regarding procreation [4]. In this context we can see that feminists' positions on the morality of the selective abortion of normal female fetuses depend on culture, ethnicity, class and race to which they belong.

Modern philosophers, discussing about successful opposition to abortion, note two necessary conditions. Firstly, it have to be shown that abortion is immoral, and at the same time the fetuses have the right to life or "interests that overrule a future mother's substantial interest in terminating an unwanted pregnancy" [3]. So, we can find appropriate assertions within ideological heritage of conservative bioethics and Christian religion which preach ideas of morality, humanism and equality through centuries up to now.

First of all, according to conservative bioethics and Christian religion, unborn child is not less valuable than any representative of the human race. Unborn child receives soul from conception, that is why he or she has already been a human by his or her ontological status. Also, conservatives and Christians state that pregnant woman has already been as a mother and must be responsible for her little innocent child. An unborn child is not protected and only mother has the exceptional right (and obligation) to save its life. In the context of Christian teaching every human is the creature of God; moreover, human is created in the image and likeness of God and is a child of Creator. Given these circumstances, it is unacceptable to kill an unborn child who has received life from God. The last but not least, killing a person is forbidden and condemned by the Christian religion. That is why Christians oppose abortion, which is not merely a grave sin, but the greatest immoral act of human. When we even consider this problem beyond religious terms, anyway depriving an unborn child of life is immoral.

Obviously, this is basic, idealistic and general position on this problem, at the same time there are exceptional cases, for instance, threat to life of mother and baby, severe defects of fetal development, etc. Under these circumstances, abortion seems more justified, although its substance does not change fundamentally.

In fact, there is great discussion on the morality of abortion under conditions of some medical indications, assumptions or forecasts. Perry Hendricks presented the impairment argument for the immorality of abortion. The argument is based on the premise that impairing a fetus with fetal alcohol syndrome is immoral, and on the principle that if impairing an organism is immoral, impairing it to a higher degree is also - the impairment principle. If abortion impairs a fetus to a higher degree, then this principle entails abortion is immoral [1]. Another philosopher, Bruce P. Blackshaw, argues that abortion does not impair an organism in the way fetal alcohol syndrome does, and showed that interest theorists can avoid the argument [1].

Similar discussions can be observed regarding the morality of abortion of a fetus with Down syndrome. On the one hand, this is a serious genetic disease that can cause a difficult life for the child and his or her parents. On the other hand, these special children can even be very talented and achieve great success in various fields of social life, especially in the arts, sports, etc. We can say from philosophical perspective: children with special needs can be both - onus or happiness for their parents. In such cases the choice of abortion depends on the moral values and spiritual strength of parents.

Practice confirms that religion has a direct impact on people's attitude to abortion. Actually, Christian Church takes an active and clear position to protect the lives of unborn children. But contemporary world is very diverse and controversial: religious people and atheists, rationalists and agnostics, nations of the Far East and the European West must interact, communicate, and solve common problems. In particular, European Union's citizens are offered two ideological systems which are largely at odds with each other: liberal and Christian. As Frank Turner states, Europe is 'secular' in that there is a clear distinction (not separation) between the realms of church and state. The path of secularisation was confidently predicted to pass from secularity to secularism [7]. 


\section{"PROFESSIONAL AND COMMUNICATION CULTURE OF THE FUTURE DOCTOR: LINGUISTIC, PEDAGOGICAL AND PHILOSOPHICAL ASPECTS”}

It is important to understand the peculiarities of these processes. Frank Turner explains: secularisation is the prolonged cultural process by which almost every field of study and action is seen to have an inherent logic and autonomy, and is not to be governed by extrinsic religious considerations [7].

At the same time, secularity, in the political arena, entails the procedural impartiality of the state and of civic institutions - between religions, and between religious and non-religious groups. Public debate may occur freely between world-views, but none may claim state sponsorship.

And the last but not least, secularism, more assertive in Europe than elsewhere, proposes the exclusion of religious belief and expression from public life. In aspiring to be the legitimate judge of the religious sphere, secularism claims not merely separation from religion but control over it [7].

\section{List of literature}

1. Blackshaw B. P. The impairment argument for the immorality of abortion revisited / B. P. Blackshaw // Bioethics. - 2019. - Vol. 34, Issue 2. - Access mode : https:// doi.org/10.1111/bioe.12698.

2. Dodds S. Feminist bioethics / S. Dodds // International encyclopedia of ethics. - 2013. - Access mode : https://doi. org/10.1002/9781444367072.wbiee601.

3. Kaposy C. Two stalemates in the philosophical debate about abortion and why they cannot be resolved using analogical arguments / C. Kaposy // Bioethics. - 2012. Vol. 26, Issue 2. - P. 84-92. - Access mode : https://doi. org/10.1111/j.1467-8519.2010.01815.x.

4. Moazam F. Feminist discourse on sex screening and selective abortion of female foetuses / F. Moazam //

\section{References}

1. Blackshaw, B.P. (2019). The impairment argument for the immorality of abortion revisited. Bioethics, 34, 2. Retrieved from: https://doi.org/10.1111/bioe.12698.

2. Dodds, S. (2013). Feminist bioethics. International encyclopedia of ethics. Retrieved from: https://doi. org/10.1002/9781444367072.wbiee601.

3. Kaposy, C. (2012). Two stalemates in the philosophical debate about abortion and why they cannot be resolved using analogical arguments. Bioethics, 26, 2, 84-92. Retrieved from: https://doi.org/10.1111/j.1467-8519.2010.01815.x.

4. Moazam, F. (2004). Feminist discourse on sex screening and selective abortion of female foetuses. Bioethics,
Under these conditions, we can state that there is threat of depreciation of the moral values by control over religion which is keeper and defender of the moral norms in a society. So, it is necessary to maintain morality in public relations and, above all, in the Health Care.

Conclusions and Prospects for Research. So, ideological foundations of modern doctor must be based on the humanistic values' system. It means that health, safety and life of human, including unborn children, have to be accepted as the highest values. At the same time moral responsibilities of doctor is related to implementing of these values into practice.

Therefore, there is a need for further research that will help to reconcile liberal, feminist and religious moral values in Health Care. It can be interdisciplinary investigation of humanitarian and bioethical content.

Bioethics. - 2004. - Vol. 18, Issue 3. - Access mode : https:// doi.org/10.1111/j.1467-8519.2004.00390.x.

5. Rajczi A. Abortion, competing entitlements, and parental responsibility / A. Rajczi // Journal of Applied Philosophy. - 2009. - Vol. 26, Issue 4. - Access mode : https://doi.org/10.1111/j.1468-5930.2009.00462.x.

6. Simkulet W. Substance, rights, value, and abortion W. Simkulet // Bioethics. - 2019. - Vol. 33, Issue 9. - Access mode : https://doi.org/10.1111/bioe.12616.

7. Turner F. S. J. Catholic social teaching and Europe / F. S. J. Turner // New Blackfriars. - 2012. - Vol. 93, Issue 1044. - Retrieved from : https://doi.org/10.1111/j.17412005.2011.01478.x.

18, 3. Retrieved from: https://doi.org/10.1111/j.14678519.2004.00390.x.

5. Rajczi, A. (2009). Abortion, competing entitlements, and parental responsibility. Journal of Applied Philosophy, 26, 4. Retrieved from: https://doi.org/10.1111/j.14685930.2009.00462.x.

6. Simkulet, W. (2019). Substance, rights, value, and abortion. Bioethics, 33, 9. Retrieved from: https://doi. org/10.1111/bioe.12616.

7. Turner, F.S.J. (2012). Catholic social teaching and Europe. New Blackfriars, 93, 1044. Retrieved from: https:// doi.org/10.1111/j.1741-2005.2011.01478.x. 